\title{
The Anatomy of Lepidodendron aculeatum, Sternb.
}

\author{
BY \\ A. C. SEWARD, F.R.S. \\ Fellow of Emmanuel College, Cambridge.
}

With Plate XXVI, and Text-figures I-3.

\begin{abstract}
DIFFICULTY which constantly confronts the palaeobotanist is that A only in rare instances is he in a position to supplement an account of internal structure by a description of external features. The absence of external characters from petrified material and the lack of structure in specimens with well-preserved surface features necessitate the use of two series of specific names: the same plant must frequently be known under two designations, one having reference to anatomical structure, and the other to external features.
\end{abstract}

The late Professor Williamson wrote in his second Memoir 'On the Organization of the Fossil Plants of the Coal-Measures' " : I am satisfied that all attempts to apply specific names to the plants of the Coal-Measures can but be provisional, until we learn more than we at present know of the effects of age upon their form and organization. Still, though they may not have any permanent value, such names are necessary for working purposes.' To those botanists who worked with Professor Williamson this statement affords but a partial reflection of the vigorous protests against the institution of specific names which he frequently made in conversation.

In the case of several species of Lepidodendreae founded on anatomical characters we are unable to give a satisfactory account of the external characters : it is not only a question of correlating species founded respectively on impressions and petrifications, but the choice of a generic name may be a serious difficulty.

The two genera Lepidodendron and Lepidophloios are, as a rule, easy to distinguish by the form of the leaf-cushions and leaf-scars, but we are not in a position to assign with confidence a petrified lepidodendroid stem, on anatomical evidence alone, to one or other of these genera. In I894,

$$
1 \text { Williamson ('72), p. } 3 \text { 10. }
$$

[Annals of Botany, Vol. XX. No, LXXX. October, 1906.] 
Williamson wrote:- ' It appears to me that much uncertainty exists amongst Palaeobotanists respecting the structures that distinguish Lepidodendron from Lepidophloios '.' The specimen described below adds point to this opinion.

A few examples of lepidodendroid stems founded on anatomical characters serve to illustrate the grounds on which one or other of these two generic names has been used.

The specimens described by Binney, in 1862 , as Sigillaria vascularis and Lepidodendron vasculare ${ }^{2}$ were afterwards recognized as one and the same type. Carruthers ${ }^{3}$ identified the species, founded on anatomical characters, with Lepidodendron selaginoides Sternb., but the nature of the evidence on which the anatomical structure of Lepidodendron vasculare was referred to Sternberg's species, founded on external characters, is not stated. On the strength of $\mathrm{Mr}$. Carruthers' identification we may regard Lepidodendron vasculare, Binney, as a well-defined anatomical type associated in some cases, though not necessarily in all, with the external features of Lepidodendron selaginoides, Sternb., which is a synonym of L. Sternbergii, Brongn. ${ }^{4}$. The common practice of speaking of Binney's type as L. selaginoides is, I think, unfortunate : though a comparatively small point, the name $L$. vasculare has the advantage of not committing us to the inference that all stems with the type of structure associated with Binney's species necessarily agree in the form of the leaf-cushions with the plant named by Brongniart $L$. Sternbergii, and by Sternberg $L$. selaginoides.

The species described by Witham ${ }^{5}$ as Lepidodendron Harcourtii has been investigated by several botanists since $183^{2}{ }^{6}$. Some of the specimens originally included by Williamson in Witham's species were subsequently recognized by him as distinct, and referred to a new species Lepidodendron fuliginosum $^{7}$; for this type Solms-Laubach proposed the name L. Williamson ${ }^{8}$, but the former designation has been generally adopted. The true Lepidodendron Harcourtii is considered by Kidston to be a species of the genus Lepidophloios as 'it has all the peculiarities' ${ }^{9}$ of that genus, but no satisfactory evidence has been adduced as to the external features of Witham's anatomical species.

In I 890 Messrs. Cash and Lomax ${ }^{10}$ mentioned a petrified stem in their possession - 'whose external surface is marked by tolerably well-preserved characters, which leave no doubt that it must be referred to the genus Lepidophloios as defined by Sternberg'-exhibiting the type of structure

1 Williamson ('94), pp. 423, 424, footnote.

3 Carruthers ('69), p. I79.

2 Binney ('62).

5 Witham. ('32).

6 Bertrand ('91) has given a comprehensive historical sketch of our knowledge of L. Harcourtii in his Memoir on the anatomy of the species.

7 Williamson ('87).

- Kidston ('01), p. 59 .

${ }^{8}$ Solms-Laubach ('87).

${ }^{10}$ Cash and Lomax ('90). 
designated by Williamson Lepidodendron fuliginosum. This identification has since been confirmed by Kidston ${ }^{1}$ and by Weiss ${ }^{2}$.

The large stems from Arran named by Williamson ${ }^{3}$ Lepidodendron Wunschianum have been described as bearing Halonial branches, and for this reason they have been referred to the genus Lepidophloios ${ }^{4}$. It has been suggested that the Arran species may be specifically identical with Lepidodendron Harcourtii ${ }^{5}$, but the evidence available does not justify a positive statement as to identity.

The petrified specimens from the Lower Carboniferous beds of Pettycur, near Burntisland, on which Williamson founded the species Lepidodendron brevifolium ${ }^{6}$, in all probability possessed the external characters of $\mathrm{L}$. $\mathrm{Vel}$ theimianum ${ }^{7}$. A recent discovery by Mr. Lomax enables us to refer Williamson's type Lepidodendron mundum ${ }^{8}$ to the genus Bothrodendron, and Dr. Scott has in his possession a specimen with the external characters of $L$. obovatum showing well-preserved internal structure ${ }^{9}$.

Reference may be made to Lepidophloios acadiamus, Daws., and to Lepidodendron Derbyi, Ren., as additional examples of lepidodendroid plants in which internal structure and external features occur together. Sir William Dawson ${ }^{10}$ described Lepidophloios acadianus in 1866 from the Canadian Coal-Measures, and an additional account of the species was published by the same author in 1897 .

An example of this species described by Dawson as a Halonial branch bearing two rows of cone-scars may be compared with the specimen recently dealt with by Weiss ${ }^{11}$, but the anatomical preservation of the Canadian plant, as represented in the somewhat rough sketches in the earlier paper and in the microphotographs by Prof. Penhallow in the later account, is too imperfect to enable us to attempt a satisfactory comparison with British anatomical types.

Mr. Kidston ${ }^{12}$ regards Lepidophloios acadianus as specifically identical with L. laricinus, Sternb.

In $1890 \mathrm{M}$. Renault ${ }^{13}$ proposed the name Lycopodiopsis Derbyi for a Brazilian specimen exhibiting external features and internal structure; he described the anatomy of the central cylinder as differing in important characters from that of the Lepidodendron type. The acquisition of additional specimens from Brazil enabled M. Zeiller ${ }^{14}$ to modify Renault's interpretation, and to identify the species as a true Lepidodendron allied

1 Kidston ('93), p. 343 ; ('01), p. $5^{8 .}$

3 Williamson ('722).

5 Seward and Hill ('00), p. 92 I.

7 Kidston ('01), p. 60.

2 Weiss ('03), p. 218.

4 Kidston ('01), p. 59.

6 Williamson $\left(72^{2}\right)$, p. 3 I O.

8 Williamson ('89).

9 I am indebted to Dr. Scott for generously lending me his specimen of $L$. obovatum for examination. [Since this was written, Dr. Scott has published a description of his specimen. See Annals, Vol. XX, p. 3I 7, 1906.]

10 Dawson ('66), ('97).

13 Renault ('90).

11 Weiss ('03).

14 Zeiller ('98).

12 Kidston ('86).

C C 2 
anatomically to $L$. Harcourtii, and in the form of the leaf-cushions possibly identical with $L$. Pedroanum, Carr. ${ }^{1}$

Description of Specimen. The fossil which forms the subject of the following description has long been in the collection of the Cambridge Botany School, and several years ago Mr. C. A. Barber, then University Demonstrator, had a single transverse section cut. On re-examining the specimen and the section I was surprised to find the preservation of the tissues much more satisfactory than my recollection of it led me to expect. I am unable to give any information as to the history of the fossil ; it was undoubtedly obtained from the English Coal-Measures, but there is no record of the locality. The general appearance of the calcified tissues presents a striking resemblance to that of some sections in the Binney Collection in the Sedgwick Museum, Cambridge, obtained from the clayironstone of the Coal-Measures near Dudley ${ }^{2}$.

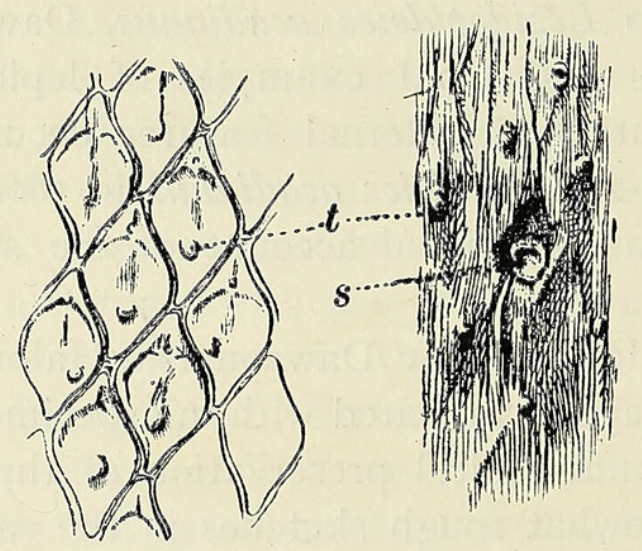

A
B

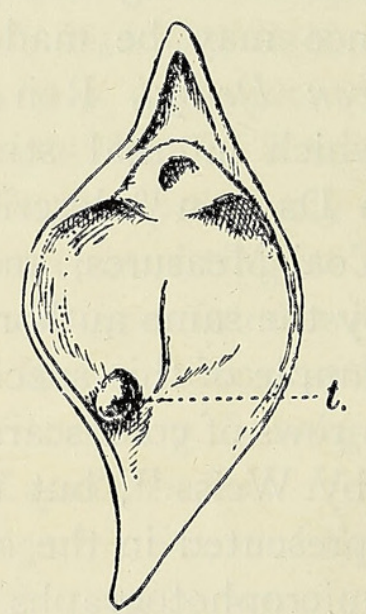

C

FIG. I.

The piece of stem is $6.8 \mathrm{~cm}$. long, and has a diameter of $4.8 \times 4.5 \mathrm{~cm}$. A thin layer of coal, approximately $.5 \mathrm{~mm}$. thick, covers a portion of the surface. Part of the surface (Pl. XXVI, Fig. I ; text-fig. I, A. C) is almost intact: the leaf-cushions, $I .5 \mathrm{~cm}$. long, are prolonged both upwards and downwards in tapered and slightly curved terminations. A ligular pit may be recognized on some of the cushions, as also the position of the leaf-scars, but the preservation is not sufficiently good to enable one to make out the parichnos-scars. The cushions are flat or slightly depressed; on each a small tubercle (Text-fig. $I, t$ ) forms a conspicuous feature, occurring either on the median line or near one edge in the lower third of the cushion region. These scars probably mark the position of leaf-traces which the shrinkage and depression of the tissues have rendered apparent on the surface of the stem. For the most part the surface has suffered partial decortication :

1 Carruthers $\left(69^{2}\right)$,

2 Seward ('99)。 
the depression shown in Text-fig. I, B. $s$, which looks like a small branchscar, appears on examination of the tissues to be the result of a wound. The dark tissues seen at C, Fig. 5, Pl. XXVI, a section cut through the scar (Text-fig. I, B. s), marks the position of the partially destroyed cortex and wound periderm.

The external characters point to Lepidodendron aculeatum, Sternb., as the species with which the form of the leaf-cushions agrees most closely. There can at least be no doubt as to the genus to which the fragment belongs. The geological range of $L$. aculeatum in Britain is stated by Kidston ${ }^{1}$ to be from the Millstone Grit to the Upper Coal-Measures.

The transverse section, represented natural size in Fig. 5, Pl. XXVI, illustrates the imperfect state of preservation of the slightly excentric stele, the tissues of which have been considerably shattered, though in places the structure is very clearly shown. The largest diameter of the somewhat flattened stele, measured from the outer edge of the xylem, reaches $I \mathrm{~cm}$. There is no trace of any secondary xylem; the primary xylem consists of a tube of scalariform tracheids, usually about six tracheids broad, with narrow protoxylem-elements at the outer edge forming fairly prominent teeth of the single or double type (Text-fig. $2, x$ ) as in Lepidodendron Harcourtii and L. fuliginosum.

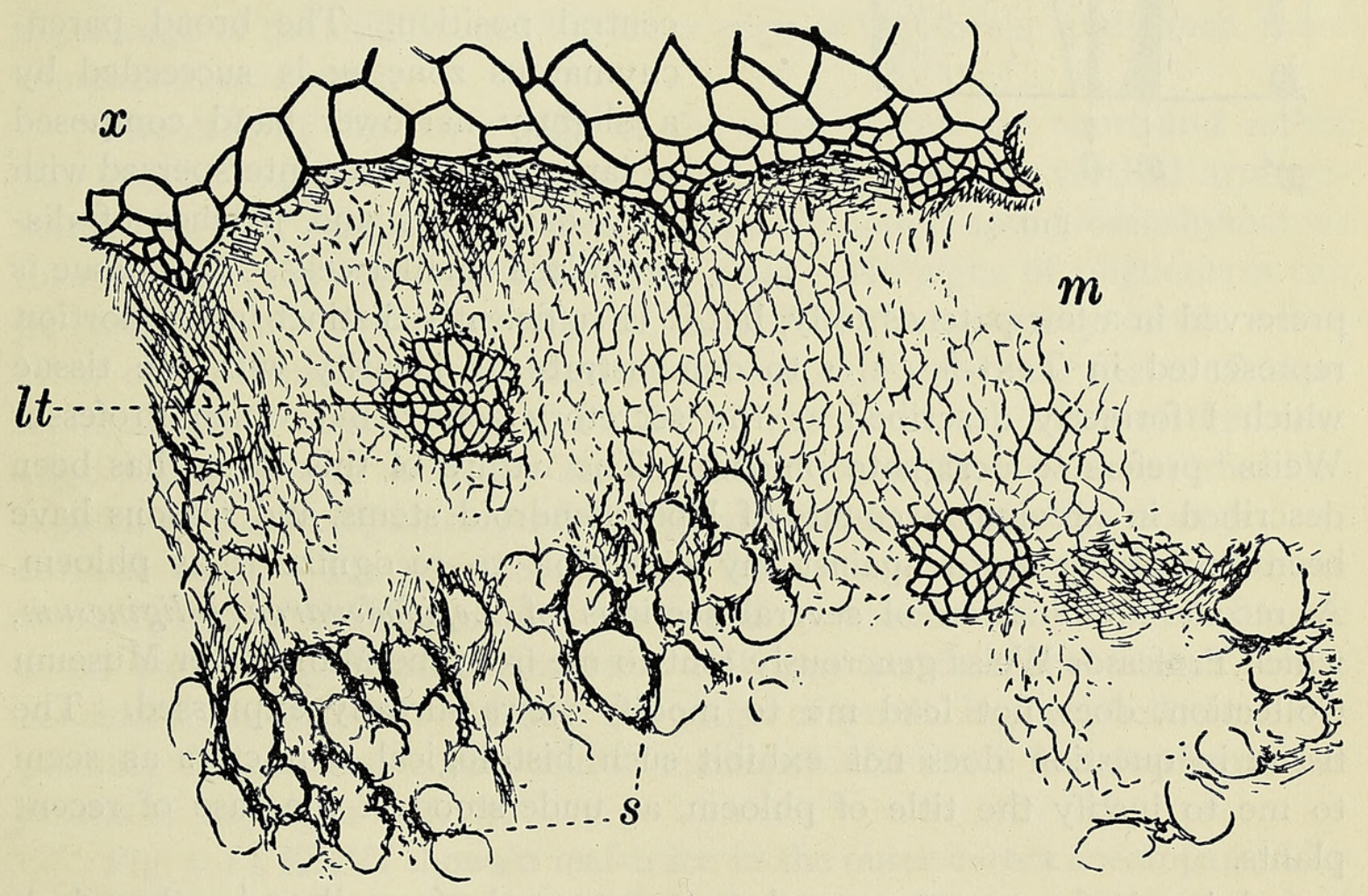

FIG. 2.

Such of the pith-tissue as remains exhibits the histological features usually met with in this region of lepidodendroid stems. The zone between

${ }^{1}$ Kidston ('94), p. 251. For figures of this species, see Zeiller ('88), Pl. LXV. Figs. I-7 ; also Kidston ('01), p. 44, and Zalessky ('04). 
the outer edge of the wood and the inner cortex has suffered considerably, either from disorganization of the tissues before petrification, or perhaps to a large extent from the effects of secondary crystallization. In the portion shown in Text-fig. 2, the preservation is exceptionally good; the xylem is succeeded externally by a broad band of small-celled parenchyma $(m)$ which is darker and denser along its inner margin. This is the tissue which previously has been described as the meristematic zone ${ }^{1}$; it is composed exclusively of short parenchymatous cells, and in other examples of Lepidodendron it is known to be the seat of secondary growth. In the portion of this zone seen in Text-fig. 2, there are no indications of meristematic activity, but a few radially elongated cells occur in other parts of the same section which are identical in form with the elements figured in some of the specimens of $L$. fuliginosum from the Binney Collection.

The leaf-traces follow an almost vertical course in the meristematic zone, and they pass through the cor-

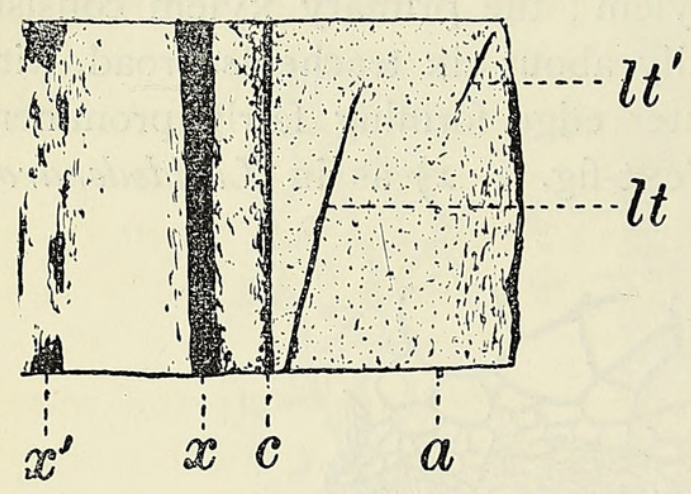

FIG. 3. tical region at an unusually small angle (Text-fig. $3, l t$ ). The xylem-strand as seen at $l t$, in Text-fig. 2 , is approximately circular in outline with the smallest tracheids in a more or less central position. The broad parenchymatous zone $m$ is succeeded by a slightly narrower band composed of large clear spaces interspersed with very dark lines and patches of disorganized smaller cells. This tissue is

preserved in a few patches only, but it is sufficiently distinct in the portion represented in Text-fig. $2, s$ to demonstrate its identity with the tissue which I formerly described as the secretory zone ${ }^{2}$, but which Professor Weiss ${ }^{3}$ prefers to designate phloem. The nature of this tissue has been described in previous accounts of lepidodendroid stems, and reasons have been brought forward against my objection to recognize it as phloem. A recent examination of several sections of Lepidodendron fuliginosum, which Professor Weiss generously sent to me from the Manchester Museum Collection, does not lead me to modify views already expressed. The tissue in question does not exhibit such histological characters as seem to me to justify the title of phloem, as understood in the case of recent plants.

A band of compact parenchyma composed of small and rather dark elements abuts on the secretory zone; this is the inner cortex (Textfig. $3, c$ ), and it appears to be identical in structure with the corresponding region in other lepidodendroid stems. The boundary between the inner

$$
{ }^{1} \text { Seward ('99), ('02). } \quad{ }^{2} \text { Seward, loc. cit. } \quad{ }^{3} \text { Weiss ('01), ('03). }
$$


and middle cortex is clearly defined by the junction of the vertical rows of the short cells of the former with the loose tissue of irregularly branched and hypha-like cells of the latter, which tend to assume a horizontal rather than a vertical direction.

Numerous leaf-traces in slightly oblique transverse section occur in the middle cortex. A leaf-trace as seen in this region (Fig. 4, Pl. XXVI) consists of a somewhat tangentially elongated xylem-strand $(x)$ separated by a few layers of delicate elongated and narrow cells $(b)$ from a patch of dark disorganized tissue in continuity with the secretory zone. The whole trace is enclosed by a few layers of parenchymatous cells (peridesm), of which those on the adaxial side often assume a radially elongated form (Fig. $4, p$ ). The structure of a leaf-trace is shown in longitudinal section in Fig. 3, Pl. XXVI. In the actual specimen the spiral protoxylem-elements are clearly seen, while the scalariform metaxylem-tracheids show a slight tendency towards a reticulate form of pitting. The xylem is shown at $x$ and the disorganized cells of the secretory zone at $s$ in Fig. 3, Pl. XXVI. The contrast between the compact peridesm $(p)$ and the loose cortex is seen at $p . c$.

The clear line near the surface of the transverse section, reproduced in Fig. 5, Pl. XXVI, represents a break in the tissue filled with mineral substance, immediately internal to the sharply defined junction between the outer edge of the middle and the inner edge of the firmer and much more compact outer cortex.

The cells at the inner edge of the outer cortex are short and rather flat and in longitudinal sections exhibit a fairly regular vertical arrangement, but they gradually assume a more elongated and prosenchymatous form towards the outer surface of the stem. No signs of phelloderm can be detected, nor are there any indications of the secretory canals which often occur immediately internal to the secondary cortical tissue of other lepidodendroid stems. Fig. 6, Pl. XXVI represents a portion of the outer edge of a transverse section. The superficial tissue has been converted into a patch of pure coal, which sends irregular threads between the disorganized cortical cells. The gradual passage from coal to well-preserved tissue reminds one of the appearance presented by sections of silicified Liassic wood partially converted into jet ${ }^{1}$. It may be that the branch under consideration had not reached the stage of producing a phelloderm, or possibly the conversion into coal of the superficial tissue has destroyed the results of phellogen activity.

Fig. 2, Pl. XXVI shows a leaf-trace in the outer cortex accompanied by a large crescentic parichnos which is simply an accompanying strand of middle cortex. In structure the leaf-traces appear to be identical with those described in sections from the Binney Collection referred to, Lepidophloios fuliginosus ${ }^{2}$. The boundary between the parichnos and outer 1 Seward ('04), p. 66, P1. VIII, Figs. I and 2. 
cortical tissue is seen at $a$, Fig. 2, Pl. XXVI; the secretory strand and xylem with the intervening cambiform cells are shown at $s, x$ and $b$.

The two dark strips extending from the surface of the section seen in Fig. 5, c, and converging in the inner cortex consist of partially destroyed tissue bounded externally by cortical cells characterized by the presence of numerous secondary septa parallel to the wounded surfaces. The area between the two dark lines in the cortex is partly occupied by shrunken and isolated cells, which appear to have fallen apart as the result of the destruction of the middle lamellae. The xylem-ring internal to the injured region exhibits the normal structure.

The anatomy of the specimen (Fig. I) possessing the surface characters of Lepidodendron aculeatum exhibits an exceedingly close agreement with that type of structure which it has been customary to describe as Lepidophloios fuliginosus. So far as I am aware the only reference to the structure of Lepidodendron aculeatum previously published is by Prof. Bertrand $^{1}$, who has mentioned the occurrence of petrified portions of suberous tissue in the nodules of Hardinghen, which are probably referable to this species. It has been pointed out by Weiss that the leaf-traces in the stem described by him as a biseriate Halonia, and referred on anatomical grounds to L. fuliginosus, pursue an almost horizontal course in the middle cortical region $^{2}$ : this is also the case in sections of other specimens of the same type which I have had an opportunity of examining. The steeply ascending course of the traces in the branch of Lepidodendron aculeatum (Text-fig. 3) constitutes a distinguishing feature-of how much value it is difficult to say. A comparison of the previously published figures of small branches of Lepidodendron fuliginosum with those given in this paper demonstrates a striking similarity which, with the exception of the course of the leaf-traces, seems to amount to identity. The age of the branch does not enable us to say anything as to the nature of the secondary xylem, which in older specimens constitutes a characteristic peculiarity of L. fuliginosum.

Such evidence as is available would seem to point to the absence of trustworthy criteria enabling us to separate, on anatomical grounds, Lepidophloios and Lepidodendron. Weiss refers his biseriate Halonia to the former genus ' on the strength of its internal structure' 3 , but it is questionable whether the present state of our knowledge of lepidodendroid anatomy is sufficiently accurate to render this argument valid. Mr. Kidston, ${ }^{4}$ who

1 Bertrand, Cornaille and Hovelacque ('97), p. 49I ; Bertrand ('99), p. 391.

2 Weiss ('03), p. 223.

s Weiss ('03), p. 220. It should be mentioned that Prof. Weiss (loc. cit.) adds :-' as, however, an identification based solely on the internal structure might be disputed by some, I would seek to strengthen my conclusion by evidence from specimens showing external markings which can be identified with Lepidophloios and which at the same time possess only two rows of tubercles.'

Kidston ('05), p. 538 . 
dissents from Prof. Weiss's interpretation of the tuberculated branch, expresses the opinion that the anatomical characters are not identical with those of the true Lepidodendron fuliginosum, though he recognizes that Weiss's specimen belongs to the same type of structure as the vascular axis of that species. The differences mentioned by Kidston do not appear to me of sufficient importance to serve as an objection to the use of the term L. fuliginosum on anatomical grounds; but the more important point is, the existence of this type of anatomical structure does not necessarily imply that the stem exhibiting it possessed the surface features of Lepidophloios. Mr. Kidston regards the tuberculated specimen as a fertile branch of Sigillaria discophora (Ulodendron minus). It would lead us too far afield to enter into the arguments for or against the reference of the fertile branch to Lepidophloios, but the foregoing description justifies the view that on anatomical evidence alone we cannot in the present state of our knowledge safely assume that the type of structure described by Williamson as Lepidodendron fuliginosum is the exclusive possession of Lepidophloios. Dr. Scott gave expression to this view when he wrote :'So far as is known, however, there is no constant difference in internal structure between Lepidophloios and Lepidodendron ${ }^{\text {.' }}$

Without discussing the value of the presence of Halonial tubercles as a mark of distinction between Lepidophloios and Lepidodendron, I submit that it is better to refrain from attempts to separate these two genera on purely anatomical evidence. The fragmentary nature of our material and the almost constant absence of external features in the case of petrified specimens are obstacles in the way of satisfactory identification and correlation; it is better to recognize the limitations imposed by imperfect knowledge, and to rest content with the application of specific terms to anatomical types without regard to those rare cases in which external and internal characters are supplied by the same specimen. The same anatomical type, or rather what the fragments at our disposal lead us to regard as the same type, does not necessarily imply identity in external features. Our acquaintance with the anatomy of Palaeozoic Lepidodendreae is much too meagre and superficial to enable us to judge of the degree of correspondence between the two kinds of characters available for specific definition. I would therefore speak of the specimen described above as belonging to the type Lepidodendron fuliginosum, a type of structure which occurs in association with Lepidophloios as well as with Lepidodendron leaf-cushions.

The present state of our ignorance on many histological points connected with the Lepidodendreae as well as in regard to grosser anatomical characters affords a strong plea for a thorough comparative examination of the Palaeozoic Lycopods.

\footnotetext{
${ }^{1}$ Scott ('00), p. I23.
} 
In his address to the Botanical Section of the British Association, in 1896 , Dr. Scott said :- ' We are now in possession of a magnificent mass of data for the morphology of the Palaeozoic Lycopods, and have perhaps hardly yet realized the richness of our material. I refer more especially to specimens with structure, on which, here as elsewhere, the scientific knowledge of fossil plants primarily depends "'. The revision of this material, as regards both the organization as well as the extension of the data, is an urgent need.

$$
{ }^{1} \operatorname{Scott}(' 96) \text {. }
$$

\section{BIBLIOGRAPHY.}

Bertrand, C. E. ('91): Remarques sur le Lepidodendron Harcourtii de Witham. Trav. et Mém. des Facultés de Lille, Tome II, Mém. vi, Lille, I89I.

('99): Premières observations sur les nodules du terrain houiller d'Hardinghen.

C. Rend. de l'Assoc. Franç., I899, p. 39 I.

Bertrand, C. E., F. Cornaille et M. Hovelacque ('97): Remarques sur la structure des Isoètes. C. Rend. de l'Assoc. Franç., r 897 , p. 49I.

Binney, E. W. ('62) : On some fossil plants, showing structure, from the Lower Coal-Measures of Lancashire. Quart. Journ. Geol. Soc., vol, xviii, p. Io6.

Carruthers, W. ('69): On the structure of the stems of arborescent Lycopodiaceae of the CoalMeasures. R. Micros. Soc., vol. ii, p. 177, 1869.

$\left(' 69^{2}\right)$ : On the plant remains from the Brazilian Coal-beds, with remarks on the Genus Flemingites. Geol. Mag., vol. vi, p. 5, 1869.

Cash, W., and J. Lomax ('90): On Lepidophloios and Lepidodendron. Brit. Assoc. Rep. (Leeds), p. 810.

DAwson, J. W. ('66): On the condition of deposition of Coal, more especially as illustrated by the Coal-Measures of Nova Scotia and New Brunswick. Quart. Journ. Geol. Soc., vol. xxii, p. 95 .

Measure Genus Lepidophloios as illustrated by specimens from the Coaliv, p. 57 .

Kidston, R. ('86): Catalogue of the Palaeozoic plants in the Department of Geology and Palaeontology, British Museum (Natural History). London, I 886.

('93): On the fossil plants of the Kilmarnock, Galston, and Kilwinning Coal-fields, Ayrshire. Trans. R. Soc. Edinburgh, vol. xxxvii, Part ii, p. $3 \circ 7,1893$.

- ('94): On the various divisions of British Carboniferous rocks as determined by their fossil Flora. Proc. R. Physc. Soc. Edinburgh, vol, xii, p. I83. .

('01) : Carboniferous Lycopods and Sphenophylls. Trans. Nat. Hist. Soc. Glasgow, vol. vi, Part i, p. 25, 1899-1900.

('05): On the internal structure of Sigillaria elegans of Brongniart's 'Hist. des. Vég. fossiles.' Trans. R. Soc. Edinburgh, vol. xli, Part iii, p. 533, 1905.

Lomax, J. See Cash and Lomax ('90).

Renault, B. ('90): Notice sur une Lycopodiacée arborescente du terrain houiller du Brésil. Soc. Hist. Nat. d'Autun, I890.

ScotT, D. H. ('96): Presidential Address to the Botanical Section of the British Association. Brit. Assoc. Report (Liverpool), 1896.

$(' 00)$ : Studies in Fossil Botany. London, I900.

Seward, A. C. ('99): Notes on the Binney Collection of Coal-Measure plants. Part i. Lepidophloios. Proc. Camb. Phil. Soc., vol. x, Part iii, p. I37, 1899. 
Servard.-The Anatomy of Lepidodendron aculeatum, Sternb. $38 \mathrm{I}$

Seward, A. C. ('02) : On the so-called Phloem of Lepidodendron. New Phytologist, 1901, p. 38. ('04): Catalogue of the Mesozoic Plants in the Department of Geology. British Museum (Nat. History). The Jurassic Flora, Part ii. London, $19 \mathbf{c}_{4}$.

SEWARD, A. C., AND A. W. Hill ('00): On the structure and affinities of a lepidodendroid stem from the Calciferous Sandstone of Dalmeny, Scotland ; possibly identical with Lepidophloios Harcourtii (Witham). Trans. R. Soc. Edinburgh, vol. xxxix, Part iv, p. 907, 1900.

Solms-LaUbach, Graf ZU ('87): Einleitung in die Paläophytologie. Leipzig, 1887.

Weiss, F. E. ('01): On the Phloem of Lepidophloios and Lepidodendron. Mem. Proc. Manchester Lit. and Phil. Soc., vol. xiv, Part iii, p. I.

- ('03): A biseriate Halonial branch of Lepidophloios fuliginosus. Trans. Linn. Soc, vol. vi, Part iv, p. 217,1903 .

Williamson, W. C. ('72): On the Organization of the Fossil Plants of the Coal-Measures, Part ii. Phil. Trans. R. Soc., vol. clxii, p. 197, 1872.

$\left(72^{2}\right)$ : Ibid., Part iii. $\quad$ I 872 , p. 283.

('87): Note on Lepidodendron Harcourtii and L. fuliginosum. Proc. R. Soc., vol. xlii, p. 6, 1887.

('89): On the Organization, \&c., Part xvi. Phil. Trans. R. Soc., vol. clxxx, p. 195,1889 .

('94): Correction of an error of observation in Part xix of the Author's Memoirs on the Organization of the Fossil Plants of the Coal-Measures. Proc. R. Soc., vol. lv, p. 423, 1894 .

Witham, H. ('32) : On Lepidodendron Harcourtii. Trans. Nat. Hist. Soc., Newcastle-upon-Tyne, $183^{2}$.

Zalessky, M. ('04): Végétaux fossiles du terrain carbonifère du bassin du Donetz. Mém. Com. Géol., I904.

Zeiller, R. ('88) : Flore fossile du bassin houiller de Valenciennes. Paris, I 888.

('98) : Sur un Lepidodendron silicifié du Brésil. C. Rend., I898 (July 25).

\section{EXPLANATION OF PLATE XXVI.}

Illustrating Mr. Seward's paper on Lepidodendron aculeatum.

Fig. I. Portion of the petrified specimen showing the leaf-cushions. (Nat. size.)

Fig. 2. Leaf-trace as seen in transverse section, cut from the specimen shown in Fig. I, in the outer cortex.

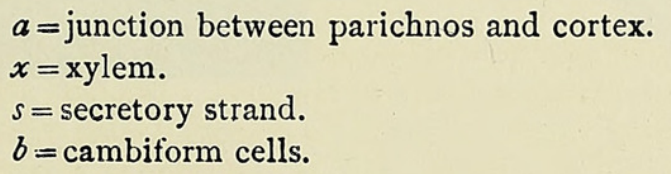

Fig. 3. Leaf-trace in longitudinal section.

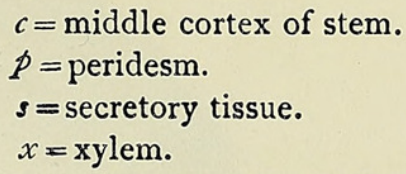

Fig. 4. Leaf-trace as seen in transverse section of the stem (Fig. I) in the middle cortical region. Lettering as in Fig. 2.

Fig. 5. Transverse section of the stem represented in Fig. I, cut through the scar $s$ shown in Text-fig. I, B.

Fig. 6. Portion of leaf-cushion converted into coal as seen at the edge of a transverse section. 

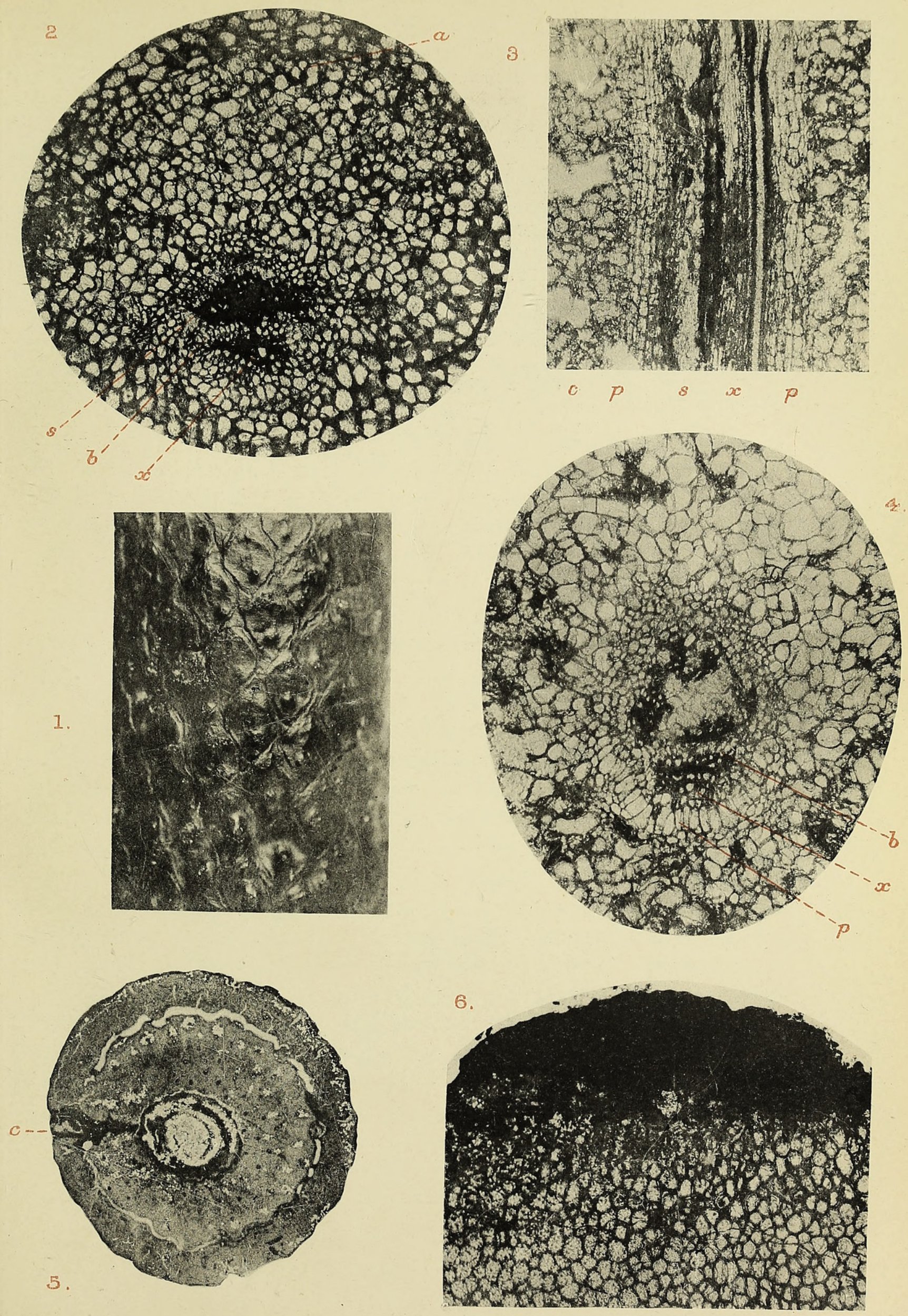

Huth, coll 


\section{$2 \mathrm{BHL}$ Biodiversity Heritage Library}

Seward, A C . 1906. "The anatomy of Lepidodendron aculeatum, Sternb." Annals of botany 20, 371-381. https://doi.org/10.1093/oxfordjournals.aob.a089108.

View This Item Online: https://www.biodiversitylibrary.org/item/234848

DOI: https://doi.org/10.1093/oxfordjournals.aob.a089108

Permalink: https://www.biodiversitylibrary.org/partpdf/318848

\section{Holding Institution}

Smithsonian Libraries

\section{Sponsored by}

Biodiversity Heritage Library

\section{Copyright \& Reuse}

Copyright Status: Not in copyright. The BHL knows of no copyright restrictions on this item.

This document was created from content at the Biodiversity Heritage Library, the world's largest open access digital library for biodiversity literature and archives. Visit BHL at https://www.biodiversitylibrary.org. 